\title{
INFLUENCE OF KNOWLEDGE MANAGEMENT ON EFFECTIVE FUNCTIONING OF PUBLIC INSTITUTIONS IN PUBLIC ADMINISTRATION
}

\author{
Seweryn CICHOŃ \\ Czestochowa University of Technology; seweryncichon@wz.pcz.pl, ORCID: 0000-0002-0383-0443
}

Purpose: The main reason for writing the article is to demonstrate the impact of knowledge management on the functioning of public administration. Multiprocessing in this respect in public administration means that knowledge management has a wide dimension.

Design/methodology/approach: The article is theoretical, its purpose is to explain the essence of the issue, which is knowledge, and to give an example of knowledge management in the context of human resource management at a state university. The theoretical scope of work includes broadly understood knowledge, its management in public administration.

Findings: In the context of achieving the objectives of the article are:

- public administration has been shown to focus on finding and accumulating areas of knowledge,

- explained what is effective knowledge management in public administration and what processes take place in it,

- features of knowledge-oriented public administration were indicated,

- categories of knowledge in public organizations are discussed in detail,

- an example of knowledge management at a university in the context of human resources was given.

Social implications: During the work on the article, the importance of the need to deepen knowledge by each member of the public organization was recognized so that it was current, broad, i.e. covering various aspects, true and bringing the expected results or solutions.

Originality/value: The novelty and innovation of the article may be the author's suggestions on how to effectively manage knowledge of public administration staff.

Keywords: knowledge, management, public administration, public authority.

Category of the paper: The article is worth recommending to the management, managers and heads of state public organizations who are constantly expanding their knowledge in the field of human resource management and government officials whose attitudes and relationships are shaped by acquired and used knowledge. 


\section{Introduction}

The management paradigm can be described on many different levels, namely: the ontological level (from the point of view of the complexity of the environment of the services provided), axiological (from the point of view of value, what management is used for) or epistemological (from the point of view of analysing cognitive processes leading to knowledge) (Nogalski, 2004). Human capital and its knowledge play a key role in the functioning of public administration (Kokot-Stępień, 2014).

"At a time when the environment of all organizations is characterized by tremendous dynamics, turbulence and even unpredictability, continuous professional development becomes a very important duty of all employees, regardless of their profession or type of professional activity. The employees' attitude to development, their motivation to learn and understanding the need to enrich and update their professional knowledge are the decisive factors for the development of professional competences, and thus the professionalization of services in the public administration sector, including local government administration in Poland" (Moczydłowska, 2011).

Hence, combining innovation, knowledge and the involvement of government officials in duties and tasks is very important (Krawczyk-Sokołowska, 2012). Knowledge must be current, not outdated, true, consistent with reality, based on facts (Kokot-Stępień, 2014). "Creating a knowledge-based, modern and extremely innovative organization is possible thanks to consistent investment in human capital. The training process is part of competence management. It is preceded by a multi-faceted study of training needs conducted using a very wide spectrum of training and development techniques (Kołodziejczyk-Olczak, 2009)" notes I. Kołodziejczyk-Olczak.

The purpose of the article is to explain the essence of the issue, which is knowledge, and to indicate the impact of knowledge management on the functioning of public administration and to give an example of knowledge management in the context of human resource management at a state university.

\section{Knowledge as an attribute to human capital}

Knowledge is the full use of information and data combined with the potential of human skills, possibilities, ideas, commitment and motivation. It is important that it is acquired, maintained, processed and stored by employees of the organization. Knowledge can be helpful in avoiding repetition of previous mistakes (Grudzewski, Hejduk, 2004). 
Currently, knowledge is dispersed and understood as a process that consists in the ability to create and maintain relationships between people, which leads to the exchange of ideas, views, their development and dissemination (Piędel, 2008).

Public administration focuses on finding and accumulating areas of knowledge, but the most important aspect of knowledge management is the need to share it. That is why it is so important to encourage all officials to share knowledge as the first step towards effective, pro-developmental management in public organizations. Where effective knowledge management is lacking, the effects of training are usually poorly used (Kossowska, Sołtysińska, 2002).

The efficient functioning of public administration is conditioned by a good understanding of markets and emerging opportunities (opportunities for action), whose early identification causes a quick response. Contemporary public organizations must be "open - and in many ways - to new ideas for action lines, open to information from the outside, actively searching the environment for weak signals that herald unknown threats and opportunities, open to information arising inside the organization" (Grudzewski, Hejduk, 2001).

Human resources are a very important part of the organization, a supply of human energy, knowledge, skills and habits that can be directed towards the organization's mission and goals, which can also affect the organization and its environment in different ways (Koźmiński, Jemielniak, 2008).

Knowledge orientation of public administration staff is treated as an important feature of their skills and attitudes in a constantly changing reality. Therefore, the amount of knowledge, professional experience, qualifications and competences as well as the level of motivation of the individual and energy for action determines the ability to work systematically and adapt to a constantly changing environment. Therefore, the quality of human capital located in public administration structures is one of the important development factors at the local and regional level. Public authorities set the main directions of socio-economic development and are responsible for its practical implementation. Assuming that development at the local and regional level is the creation of new material values, undoubtedly broadly understood knowledge plays a key role here (Tuziak, Tuziak, 2005).

\section{Effective knowledge management in public administration}

According to the Encyclopaedia of Organization and Management, organization is considered in three aspects: according to material, functional and attribute approach. In the material aspect, it is a functional institution or group consisting of intentionally organized human and material teams. On the other hand, organization in the functional aspect is a process based on the intentional grouping of people and things so that they efficiently achieve their 
goals and tasks. In turn, the attribute approach presents the attribute properties of the organization under consideration. According to this classification, public institutions in public administration fall into the third of the categories presented, i.e. the attribute approach (Encyclopaedia of Organization and Management, 1981).

In addition, a public organization can be considered with regard to the following criteria (Kaczmarek, 2001):

- the area and level of social reality in which organizations operate,

- organization size, functions and goals of the organization,

- organization structure and organizational relationship attributes,

- mechanisms of power and organizational leadership, relations with the environment,

- learning and innovation ability,

- properties of organizational culture, including organizational axiology,

- the age and experience of the organization,

- organization technology,

- organizational effectiveness.

"Implementation of tasks by public administration, and especially at the offices forming its core, each of which is a kind of public organization, in order to undertake its mission should meet the requirements of a modern organization involved in modern management processes. They are characterized by growing dynamics and the need for systemic and comprehensive analysis of the environment as well as the need to improve the operation of all organizations and make appropriate changes. Hence the need for systematic learning of contemporary organizations, which becomes the basic premise for long-term and effective action" (Potoczek, 2011). Efficient knowledge management appears as a fundamental skill of developed societies (Galar, 2001). Thus, it also applies to the public administration sector. Effective knowledge management in public administration consists of the following processes (Probst, Raub, Romhardt, 2002; Strojny, 2000):

1. Acquiring knowledge - a significant part of knowledge resources comes from external sources (contacts with customers, suppliers, partners). You can also buy knowledge and hire external experts.

2. Developing knowledge - this process consists of acquiring skills, improving existing processes, and conducting market research. At this stage, the way in which the administration relates to new, innovative ideas and creativity of officials is learned.

3. Knowledge sharing and dissemination - it answers the following questions: Who should know? How much? On what topic? How to improve the process of knowledge dissemination? The dissemination process aims to provide access to individual information and skills of officials in such a way that they can serve the entire organization.

4. Exploiting knowledge - focusing on the productive use of existing knowledge resources of the organization, mainly overcoming routine barriers, concerns about position, overestimation of self-esteem, breaking unwritten rules, incorrectly oriented leadership. 
5. Preservation of knowledge - acquired knowledge must be preserved and accumulated. It should be selected, stored and updated. This is due to the loss of valuable intellectual resources.

6. Knowledge localization - development of methods for discovering organizational knowledge and its rapid localization, e.g. by developing structures for presenting intellectual resources in public administration.

The efficient functioning of public administration as one of the economic sectors relies on the management process in many aspects, including knowledge. Features of knowledgeoriented public administration include (Roosevell Thomas, 1998; Bartnicki, 1998):

- commitment to the vision and mission of the entrusted activities,

- effectiveness and focus on identifying appropriate actions,

- building knowledge acquisition potential,

- improving operations,

- multifunctional roles involving collaboration with other organizations,

- result referral,

- strategic thinking,

- creating conditions for improving the quality and effectiveness of operations,

- learning to develop the delivery of ever better public services,

- learning to improve processes,

- learning to disseminate new ideas, processes and procedures,

- learning to increase knowledge and shape the mechanisms for its acquisition and dissemination,

- treating every activity as a learning opportunity,

- openness to the environment,

- sensitivity to internal phenomena.

One of the roles of the staff is taking care of continuous development and following changes in organization; one needs up-to-date, reliable and professional knowledge. The knowledge of all members of a public organization develops when the following conditions are met (Armstrong, 2000):

- a strategic action plan should be developed, including knowledge definition and the skills officials should have,

- management should be prepared and able to continually develop their skills to be able to follow changes, the desire for continuous development must be awakened by the organization,

- learning and work in an organization should be combined, which means that officials are supposed to learn to solve everyday problems and take real challenges,

- management should set a good example for officials willingly to develop their skills and knowledge. 
All public administration employees, both senior and on lower level, in their knowledgeoriented activities should know the relevant categories of this knowledge (Table 1).

Table 1.

Knowledge categories

\begin{tabular}{|c|l|}
\hline $\begin{array}{c}\text { Inventory name of the } \\
\text { knowledge category }\end{array}$ & \multicolumn{1}{c|}{ Explanation of the concept } \\
\hline know - what & Knowledge represented in numbers in a set of information. \\
\hline know - why & $\begin{array}{l}\text { On the nature of scientific knowledge about principles and regularities; technical } \\
\text { and technological improvement of services through research conducted in various } \\
\text { public organizations. }\end{array}$ \\
\hline know - how & $\begin{array}{l}\text { Refers to the skills and abilities to perform various activities creating a form of } \\
\text { organizational knowledge. }\end{array}$ \\
\hline know - who & $\begin{array}{l}\text { Knowledge about who has specific skills in a given field, which translates into } \\
\text { greater effectiveness of managers' work. }\end{array}$ \\
\hline know - when & Knowledge about the convenient time of completing the task. \\
\hline know - which & Knowing what to look for. \\
\hline know - between & Knowledge about relations in a public organization. \\
\hline know - where & Knowing where to look for new solutions. \\
\hline know - whether & Knowing whether to continue working. \\
\hline know - if & Knowledge of the possible effects of activities. \\
\hline
\end{tabular}

Source: A. Kościelniak, 2000.

By recognizing the above categories of knowledge, government officials will be able to apply it in various areas of their professional activity. It should be remembered that knowledge is an indispensable element in shaping the professional career of each employee. It is not only about the self-development of the individual, improvement, training, raising qualifications; it indicates high competences but also has an impact on skills and increases with experience.

\section{Knowledge management at a university in the context of human resources - an example}

A university is a service institution that aims to provide knowledge to interested parties and create conditions conducive to the learning process (Teresiński, 2004).

An example of effective knowledge management in public administration are activities in this field at the Częstochowa University of Technology, a public university of the Silesian Province.

The university focuses on the development of social capital, assuming that (Annex to Resolution No. 330/2011/2012 of the CUT Senate of February 22, 2012):

1. Improvement is the basis for the development of human capital at the Częstochowa University of Technology and improving the qualifications of their own staff, taking into account the periods of obtaining academic degrees and titles provided by law.

2. The development of academic and teaching staff of the Częstochowa University of Technology should take place through the activities of professors and independent 
working science employees in the directions of creating scientific schools recognized at national and international level.

3. Employees who are not scientific and didactic staff constitute a very important part of the social potential of the Częstochowa University of Technology. The university should further support the development of professional qualifications, competences and career opportunities for employees who are not academic and teaching staff.

4. The development of social capital of the Częstochowa University of Technology should take into account the needs and activity of students, especially in the field of student scientific associations, sporting events and broad cultural activities.

5. Constantly supporting young academics in obtaining professional promotions, inter alia, through scholarship policy, is particularly important in the development of Częstochowa University of Technology.

6. Systematic strengthening of units in the process of obtaining further doctoral rights should be assumed as the main objectives of the Częstochowa University of Technology and habilitation in individual disciplines is important for the further development of the University.

It should be emphasized that the mission of the Częstochowa University of Technology is to create and transfer knowledge to educate students in the spirit of truth, respect for knowledge, openness to new ideas and respect for universal values. The foundation of the Częstochowa University of Technology is rich academic traditions created over the decades as a result of the work of many generations of University employees.

\section{Conclusion}

The impact of knowledge management on the effective functioning of public institutions in public administration is huge. In fact, it all starts with the knowledge in building an organization. Knowledge is needed at the workplace to carry out tasks and achieve effects. You should have knowledge of the rules and administrative procedures, computer skills, knowledge of basic programs used in offices, knowledge of foreign languages, etc. Every employee of a public organization should update and supplement knowledge as it outdates quickly. Therefore, training, courses and postgraduate studies are in this respect an important element of self-development of each member of the organization. Management should periodically organize trainings and treat them as organized activities in the field of expanding knowledge, in which there is a phase of planning, organizing, implementing and controlling. The role of the management is to assess the knowledge of their subordinates and verify skills in the workplace and to account for tasks performed. For the objectives of the public organization to be implemented quickly, the staff must be professional, i.e. the technical 
preparation of employees for the provision of services must be of a high standard. A good way for effective management of employees' knowledge can be to set paths for professional development, which results in raising qualifications and greater skills and in the future professional promotion.

\section{References}

1. Armstrong, M. (2000). Zarządzanie zasobami ludzkimi. Kraków: Dom Wydawniczy ABC.

2. Bartnicki, M. (1998). Transformacja przedsiębiorstwa. Katowice: Wydawnictwo Akademii Ekonomicznej.

3. Dziuba, D.Y. (2000). Gospodarki nasycone informacja i wiedza. Podstawy ekonomiki sektora informacyjnego. Warszawa: UW.

4. Encyklopedia organizacji i zarzadzania (1981). Warszawa: PWE.

5. Galar, R. (2001). Gospodarka oparta na wiedzy i innowacje przełomowe. In: A. Kukliński (ed.), Gospodarka oparta na wiedzy. Wyzwanie dla Polski XXI wieku. Warszawa: PWE.

6. Grudzewski, W.M., Hejduk, I.K. (2001). Projektowanie systemów zarządzania. Warszawa: PWE.

7. Grudzewski, W.M., Hejduk, I.K. (2004). Zarządzanie wiedza w przedsiębiorstwach. Warszawa: Difin.

8. Kaczmarek, B. (2001). Organizacje: polityka, władza, struktury. MSM. Warszawa: PWN.

9. Kokot-Stępień, P. (2014). Kapitał - kluczowy czynnik rozwoju przedsiębiorstwa. In: D. Wielgórka (ed.), Współczesne problemy zarządzania w podmiotach gospodarczych i publicznych. Częstochowa: Sekcja Wydawnictw Wydziału Zarządzania Politechniki Częstochowskiej.

10. Kokot-Stępień, P. (2014). Znaczenie zasobów ludzkich w zarządzaniu procesami inwestycyjnymi w przedsiębiorstwie. In: Z. Ostraszewska, A. Wójcik-Mazur (eds.), Wybrane problemy zarządzania $w$ podmiotach gospodarczych. Częstochowa: Sekcja Wydawnictw Wydziału Zarządzania Politechniki Częstochowskiej.

11. Kołodziejczyk-Olczak, I. (2009). Rozwój firmy poprzez doskonalenie ZZL (Sygnity SA). Zarządzanie Zasobami Ludzkimi, 3-4.

12. Kossowska, M., Sołtysińska, I. (2002). Szkolenia pracowników a rozwój organizacji. Kraków: PWE.

13. Kościelniak, A. (2012). Zarządzanie kapitałem ludzkim w organizacji wiedzy. Zarządzanie $i$ Finanse, 1/3.

14. Koźmiński, A., Jemielniak, D. (2008). Zarzadzanie od podstaw. Warszawa: Wydawnictwo WAiP. 
15. Krawczyk-Sokołowska, I. (2012). Zarządzanie wiedzą w przedsiębiorstwie innowacyjnym. In: I. Krawczyk-Sokołowska (ed.), Zarzadzanie przedsiębiorstwem $w$ kontekście zrównoważonego rozwoju. Częstochowa: Sekcja Wydawnictw Wydziału Zarządzania Politechniki Częstochowskiej.

16. Moczydłowska, J. (2011). Doskonalenie wiedzy zawodowej jako element zarządzania kompetencjami w sektorze administracji publicznej. In: J. Wołejszo, A. Letkiewicz (eds.), Public management 2011. Funkcjonowanie organizacji publicznych $w$ dynamicznym otoczeniu, tom 1. Szczytno: Wydział Wydawnictw i Poligrafii Wyższej Szkoły Policji.

17. Nogalski, B. (2004). Wybór paradygmatów zarządzania przedsiębiorstwem przyszłości. In: I.K. Hejduk (ed.), Przedsiębiorstwo przyszłości. Fikcja i rzeczywistość. Warszawa: Wydawnictwo ORGMASZ.

18. Piędel, A. (2008). Style kierowania w administracji publicznej. Bezpieczeństwo i ochrona, Kwartalnik Naukowy Wyższej Szkoty Bezpieczeństwa i Ochrony, I, 1-2.

19. Potoczek, A. (2011). Administracja publiczna w procesie budowy potencjału innowacyjnego jednostki terytorialnej. In: J. Wołejszo, A. Letkiewicz (eds.), Public management 2011. Funkcjonowanie organizacji publicznych $w$ dynamicznym otoczeniu, tom 1. Szczytno: Wydział Wydawnictw i Poligrafii Wyższej Szkoły Policji.

20. Probst, G., Raub, S., Romhardt, K. (2002). Zarządzanie wiedza w organizacji. Kraków: PWE.

21. Roosevell, T.R. (1998). Zróżnicowanie a organizacje przyszłości. In: F. Hesselbein, M. Goldsmith, R. Beckhard (eds.), Organizacje przyszłości. Warszawa: Wydawnictwo Business Press.

22. Strojny, M. (2000). Zarządzanie wiedzą. Przegląd Organizacji, 2.

23. Teresiński, D. (2004). Dwie szkoły. Przegląd Organizacji, 9.

24. Tuziak, A., Tuziak, B. (2005). Innowacyjność jako element kapitału ludzkiego kadr samorządowych województwa podkarpackiego. Zeszyty Uniwersytetu Rzeszowskiego, 7.

25. Załącznik do Uchwały nr 330/2011/2012 Senatu PCz z dnia 22 lutego 2012 roku. 